\title{
Biochemical Findings in Normal and Osteoarthritic Articular Cartilage. II. Chondroitin Sulfate Concentration and Chain Length, Water, and Ash Content*
}

\author{
Alfred Jay Bollet † and Joanne L. Nance \\ (From the Departments of Preventive Medicine and Internal Medicine, University of Virginia \\ School of Medicine, Charlottesville, Va.)
}

Softening and erosion of cartilage, the characteristic early lesions of osteoarthritis, occur in sites of decreased chondroitin sulfate concentration. The role of aging and the specific biochemical events that produce this alteration in glycosaminoglycan composition have been under study in several laboratories. Collins and McElligott found increased radiosulfate fixation in these lesions compared with normal articular cartilage from the same individuals, suggesting increased synthesis of polysaccharide (1). These observations indicated an increased turnover of chondroitin sulfate in osteoarthritic cartilage lesions, and attention has become focused on the mechanism responsible for breakdown of this glycosaminoglycan.

As reported previously (2), when the cartilage proteinpolysaccharide complex was extracted from human articular cartilage obtained at autopsy, a decrease in the concentration of chondroitin sulfate but not protein was found in the areas of erosion. This observation pointed to a specific breakdown of the glycosaminoglycan, since proteolysis might be expected to cause removal of both components such as occurs after papain injection into rabbits (3). An enzyme resembling testicular hyaluronidase could be responsible, but reports of the presence of hyaluronidase in tissues other than testis were unconvincing or unconfirmed. A reevaluation of the tissue distribution of this enzyme resulted in the finding of an enzyme with most of the characteristics of testicular hyaluronidase in

\footnotetext{
* Submitted for publication August 3, 1965; accepted March 24, 1966. This work was supported by U. S. Public Health Service grants AM 03421 and AM 21,934$5 \mathrm{~K} 3$.

$\dagger$ Address requests for reprints to Dr. Alfred Jay Bollet, Dept. of Preventive Medicine, University of Virginia School of Medicine, Charlottesville, Va.
}

urine, plasma, liver, spleen, kidney, synovial tissue, and synovial fluid, but no hyaluronidase activity was detected in articular or costal cartilage (4). On the other hand, a proteolytic enzyme capable of degrading cartilage proteinpolysaccharide is present in chondrocytes (5-7). Whether protease or an enzyme resembling testicular hyaluronidase is responsible for the increased turnover of chondroitin sulfate in osteoarthritic cartilage matrix requires more definitive analysis.

Cartilage proteinpolysaccharide probably consists of multiple chondroitin sulfate chains attached to a central protein core (8). One could, therefore, predict that proteolysis would release part of the protein and associated polysaccharide from the molecule, but the chondroitin sulfate remaining would be qualitatively unchanged. On the other hand, hyaluronidase would specifically attack and degrade the chondroitin sulfate chains, leaving behind polysaccharide of lower average chain length in the zones of decreased chondroitin sulfate concentration. In addition, keratan sulfate is probably attached to the same or a similar protein core; hyaluronidase, which does not digest keratan sulfate, would cause loss of only the chondroitin sulfate, whereas protease would cause both glycosaminoglycans to be lost from the cartilage matrix. Similar glycoproteins, which are also present in cartilage matrix, are not affected by hyaluronidase. This paper reports studies of the chain length of chondroitin sulfate and the relative concentrations of chondroitin sulfate and neutral sugar in keratan sulfate and glycoprotein in human osteoarthritic and normal articular cartilage; in addition, we studied the synthesis of chondroitin sulfate in these lesions by cartilage samples in vitro and determined their water and ash content. We also analyzed the influence of 
age on these components in normal articular cartilage.

\section{Methods}

Human articular cartilage was obtained from the knee at autopsy, using a scalpel blade to cut as deeply as possible without removing underlying bone. Samples were removed from the posterior surface of the patella or from the condyles and patellar groove of the femur; abnormal areas were excised with care not to include surrounding normal zones. Both normal and abnormal samples were usually obtainable from the same joint. An attempt was made to grade the degree of abnormality from the gross findings, as described previously (2). The cartilage was stored frozen in sealed containers if not processed immediately; each specimen was diced, and weighed samples were used for analysis of the chondroitin sulfate concentration and at least one other determination. The term chondroitin sulfate as used in this study includes the total of chondroitin-4-sulfate plus chondroitin-6-sulfate, since the methods used did not distinguish between these isomers.

Ethanol fractions were prepared from cartilage samples weighing up to $250 \mathrm{mg}$ after digestion in $5 \mathrm{ml}$ of $0.05 \mathrm{~N}$

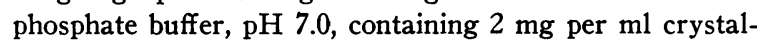
line trypsin ${ }^{1}$ for 16 to 20 hours at $37^{\circ} \mathrm{C}$ and then homogenization in a Kinematica ${ }^{2}$ for 1 minute. Insoluble debris was removed by brief centrifugation; this residue was found to have an average of $10.8 \%(\mathrm{SEM} \pm 1.2 \%)$ of the total hexosamine of the cartilage. Four $\mathrm{ml}$ of supernatant was brought to $40 \%$ ethanol by the addition of $4.0 \mathrm{ml}$ of ethanol and $1.6 \mathrm{ml}$ of aqueous $20 \%$ potassium acetate. After standing at $4^{\circ} \mathrm{C}$ overnight, the precipitate was removed by centrifugation and the supernatant brought to $50 \%$ ethanol concentration, allowed to stand overnight at $4^{\circ} \mathrm{C}$, and centrifuged. When needed, a third precipitate was collected in similar fashion by bringing the ethanol concentration in the supernatant to $75 \%$.

Each precipitate was dissolved in $4 \mathrm{ml}$ of water, and portions were used for determination of uronic acid with the carbazole method of Dische (9) and hexosamine by the method of Neuhaus and Letzring (10). Chondroitin sulfate chain length was determined by the procedure of Partridge, Davis, and Adair (11), which gives a number average molecular weight; reducing sugar determinations were done by the method of Somogyi (12) after exposure of the glycosaminoglycan solution to $0.1 \mathrm{M}$ sodium hydroxide for 24 hours and neutralization. The concentration of chondroitin sulfate used in the calculation was based on the uronic acid determination, multiplied by a factor of 2.67 .

The anthrone method (13) was used to determine the neutral sugar in the ethanol precipitates obtained from cartilage samples, using galactose as standard, after subtraction of the color development attributable to the uronic acid present in each specimen. This value represents a

\footnotetext{
1 Pentex, Inc., Kankakee, IIl.

2 Willems, Lucerne, Switzerland.
}

combination of the neutral sugar present in keratan sulfate and glycoprotein.

The in vitro synthesis of polysaccharide was studied using cartilage samples placed in ice immediately after removal at autopsy; finely diced samples weighing a total of $100 \mathrm{mg}$ were incubated in Tyrode's solution containing ${ }^{35} \mathrm{SO}_{4}$ or acetate- ${ }^{14} \mathrm{C}, 5 \mu \mathrm{c}$ per ml, at $37^{\circ} \mathrm{C}$ for $2 \frac{1}{2}$ hours, then washed five times with $0.15 \mathrm{M}$ saline and incubated overnight with trypsin as described above. Precipitates were prepared at various ethanol concentrations, washed, dissolved in water, and analyzed for uronic acid and radioactivity by liquid scintillation spectrometry. Before ${ }^{{ }^{8} \mathrm{~S}}$ was counted, samples were hydrolyzed with $0.1 \mathrm{M}$ sodium sulfate and $6 \mathrm{~N} \mathrm{HCl}$ for 4 hours at $100^{\circ} \mathrm{C}$. Specific activities were determined on the basis of the concentration of uronic acid, which implies that the molar ratio of sulfur and acetate to uronic acid was 1.0 .

To determine the water content, diced cartilage samples of approximately $50 \mathrm{mg}$ were weighed and dried in acetone for 18 to 24 hours and heated at $60^{\circ} \mathrm{C}$ for an additional 18 to 24 hours; no further weight loss was obtained by additional heating. The dried samples were weighed on a Kahn electrobalance to $\pm 0.01 \mathrm{mg}$ and placed in a muffle furnace at $1,000^{\circ} \mathrm{F}$ for 48 hours in weighed pieces of aluminum foil in crucibles. Additional heating at this temperature caused no further loss of weight. After it had reached room temperature in a desiccator over calcium chloride, the ash was weighed on an electrobalance.

Concentrations are given on a wet weight basis except for ash weights, which were determined as per cent of dry weight. Figures in tables and text are means plus or minus standard errors; $p$ values, calculated using the $t$ test, are for differences from the normal samples except where indicated.

\section{Results}

Concentration of chondroitin sulfate. As in previous studies (2), the concentration of chondroitin sulfate was decreased in the samples considered abnormal at autopsy (Tables I and II). A good correlation was observed between the gross estimate of the severity of the osteoarthritis and the decrease in chondroitin sulfate concentration. In view of this, to obtain greater objectivity in dividing samples into minimal and advanced osteoarthritis for statistical calculations, we decided to use the chondroitin sulfate concentration as the basis for division. Of the samples considered abnormal at the time of autopsy, those with a concentration below $534 \mathrm{mg}$ per $100 \mathrm{ml}$ chondroitin sulfate $(200 \mathrm{mg}$ per $100 \mathrm{ml}$ as uronic acid) were classified as advanced disease. A final decision whether or not early osteoarthritic change was present was postponed at the time of autopsy in a few instances because of uncertainty concern- 
TABLE I

Chondroitin sulfate in normal and osteoarthritic articular cartilage

\begin{tabular}{|c|c|c|c|c|c|}
\hline & \multirow{2}{*}{$\begin{array}{l}\text { No. of } \\
\text { obser- } \\
\text { vations }\end{array}$} & \multirow[b]{2}{*}{ Concentration } & \multicolumn{2}{|c|}{$40 \%$ ethanol fraction } & \multirow{2}{*}{$\begin{array}{c}\text { Hexosamine/ } \\
\text { uronic acid } \\
\text { (molar ratio) }\end{array}$} \\
\hline & & & Concentration & $\begin{array}{c}\text { Chain length } \\
\left(\times 10^{3}\right)\end{array}$ & \\
\hline Normal & 26 & $\begin{array}{c}g / 100 \mathrm{ml} \\
1.84 \quad \pm 0.13\end{array}$ & $\begin{array}{c}\mathrm{g} / 100 \mathrm{ml} \\
1.57^{\mathrm{I}} \pm 0.12\end{array}$ & $14.7 \pm 0.6$ & $1.36 \pm 0.06$ \\
\hline $\begin{array}{l}\text { All osteoarthritic } \\
\text { samples }\end{array}$ & 21 & $\begin{array}{l}0.871 \pm 0.093 \\
\mathrm{p}=<0.001\end{array}$ & $\begin{array}{l}0.706 \pm 0.09 \\
\mathrm{p}=<0.001\end{array}$ & $\begin{array}{c}9.1 \pm 0.5 \\
\mathrm{p}=\stackrel{0.001}{<}\end{array}$ & $1.39 \pm 0.15$ \\
\hline $\begin{array}{l}\text { Minimal } \\
\text { osteoarthritis }\end{array}$ & 7 & $\begin{array}{l}1.31 \pm 0.17 \\
\mathrm{p}=<0.05\end{array}$ & $\begin{array}{l}1.08 \pm 0.18 \\
p=<0.05\end{array}$ & $\begin{array}{l}11.1 \pm 0.7 \\
p=<0.01\end{array}$ & $1.45 \pm 0.15$ \\
\hline $\begin{array}{l}\text { Advanced } \\
\text { osteoarthritis* }\end{array}$ & 14 & $\begin{array}{l}0.651 \pm 0.045 \\
\mathrm{p}=<0.001\end{array}$ & $\begin{array}{l}0.519 \pm 0.042 \\
p=<0.001\end{array}$ & $\begin{array}{c}8.2 \pm 0.5 \\
\mathrm{p}=\end{array}$ & $1.37 \pm 0.09$ \\
\hline
\end{tabular}

${ }^{*} \mathrm{p}$ values for difference between minimal and advanced osteoarthritis are: total concentration of chondroitin sulfate (CS), $<0.001$; concentration of CS in $40 \%$ ethanol fraction, $<0.001$; chain length, $<0.01$.

ing the presence of softening. These samples were labeled doubtful, and those which had chondroitin sulfate concentrations well in the normal range (over $1.0 \mathrm{~g}$ per $100 \mathrm{ml}$ ) were classified as normal; the others were considered minimal osteoarthritis.

Chain length of chondroitin sulfate in the $40 \%$ ethanol fraction. The calculated values for chain length and concentration of the chondroitin sulfate in the fraction obtained by precipitation at $40 \%$ ethanol concentration are given in Table I. A highly significant decrease in chain length was observed in the abnormal specimens, consistent with depolymerization of the chondroitin sulfate. A good correlation between the chondroitin sulfate chain length and concentration in this fraction $(\mathrm{r}=0.88, \mathrm{p}=<0.001)$ was observed for the abnormal specimens.
Evaluation of chain length method. The method for chain length, based on reducing sugar activity as an end group analysis, might be erroneous if other reducing sugar was contaminating the specimens. When further attempts at purification were made by using pronase or papain in addition to or in place of trypsin to degrade the protein moiety further, or by reprecipitation of the chondroitin sulfate, the same or lower chain length values were found, rather than increased values, which might indicate separation from contaminating reducing activity. No procedure was found that gave higher values for chain length. Keratan sulfate was present in the trypsin digests, but hexosamine to uronic acid ratios and the anthrone reaction for galactose showed that very little was present in the fraction precipitated by $40 \%$ ethanol. More neutral sugar was present in the

TABLE II

Neutral sugar and chondroitin sulfate values found in normal and osteoarthritic articular cartilage

\begin{tabular}{|c|c|c|c|c|}
\hline & $\begin{array}{c}\text { No. of } \\
\text { obser- } \\
\text { vations }\end{array}$ & Neutral sugar* & Chondroitin sulfate & $\begin{array}{c}\text { Concentration of } \\
\text { chondroitin sulfate/ } \\
\text { neutral sugar }\end{array}$ \\
\hline Normal & 32 & $\begin{array}{l}m g / 100 \mathrm{ml} \\
595 \pm 1.4\end{array}$ & $\begin{array}{c}g / 100 \mathrm{ml} \\
1.23^{2} \pm 0.077\end{array}$ & $2.17 \pm 0.10$ \\
\hline $\begin{array}{l}\text { All osteoarthritic } \\
\text { samples }\end{array}$ & 30 & $\begin{array}{l}395 \pm 2.6 \\
(p=<0.01)\end{array}$ & $\begin{array}{l}0.462 \pm 0.044 \\
(p=<0.001)\end{array}$ & $\begin{array}{l}1.23 \pm 0.10 \\
(p=<0.001)\end{array}$ \\
\hline $\begin{array}{l}\text { Minimal } \\
\text { osteoarthritis }\end{array}$ & 11 & $\begin{array}{l}480 \pm 4.8 \\
(p=<0.2)\end{array}$ & $\begin{array}{l}0.723 \pm 0.051 \\
(p=<0.001)\end{array}$ & $\begin{array}{l}1.59 \pm 0.12 \\
(p=<0.01)\end{array}$ \\
\hline $\begin{array}{l}\text { Advanced } \\
\text { osteoarthritis } \dagger\end{array}$ & 19 & $\begin{array}{l}347 \pm 2.6 \\
(p=<0.001)\end{array}$ & $\begin{array}{l}0.311 \pm 0.044 \\
(p=<0.001)\end{array}$ & $\begin{array}{l}1.02 \pm 0.13 \\
(p=<0.001)\end{array}$ \\
\hline
\end{tabular}

* As galactose.

$t p$ values for difference between minimal and advanced osteoarthritis are: neutral sugar, $<0.01$; chondroitin sulfate, $<0.001$; ratio of chondroitin sulfate to neutral sugar, $<0.01$. 
precipitate obtained at $50 \%$ ethanol; the $75 \%$ ethanol precipitate contained the most neutral sugar and was virtually devoid of uronic acid. On testing the $75 \%$ ethanol fraction, no reducing sugar activity was detected with or without prior treatment with sodium hydroxide while using neutral sugar (keratan sulfate plus glycoprotein) concentrations considerably higher than were present in the $40 \%$ ethanol fractions used for chain length determination. The molar ratio of hexosamine to uronic acid was essentially the same in the $40 \%$ ethanol precipitates from the normal and abnormal specimens, indicating no greater degree of contamination in the abnormal. No correlation was found between the value found for chain length and the ratio of hexosamine to uronic acid. It seems unlikely, therefore, that contamination affected the reducing sugar values.

As a further check on the possible presence of contaminating reducing sugar, several samples were incubated with bovine testicular hyaluronidase, ${ }^{3} 1 \mathrm{mg}$ per $\mathrm{ml}$ in $0.5 \mathrm{M}$ acetate buffer, for up to 48 hours at $37^{\circ} \mathrm{C}$, and the chain length determination was repeated. The chain lengths found were never below the theoretical value for tetrasaccharide, ranging between 1,000 and 1,500; if contaminating reducing sugar was present, a lower apparent molecular weight should have been obtained. As a standard for comparison, a chain length determination was performed on pure tetrasaccharide $^{4}$; a value of 946 was found, which is close to the theoretical one.

When determinations of chain length were done without exposure to sodium hydroxide, higher values were found, presumably due to incomplete separation of the reducing ends of the polysaccharide from the peptide. A series of samples run in this fashion showed a mean $28.3 \pm 2.67\left(\times 10^{3}\right)$ for 24 normal samples and $12.3 \pm 1.24\left(\times 10^{3}\right)$ for 22 osteoarthritic samples $(\mathrm{p}=<0.001)$. The sodium hydroxide treatment gave more consistent results with lower values, particularly in the normal samples, reflecting more complete exposure of reducing end groups. It is unlikely that sodium hydroxide caused depolymerization of the chains, judging by the fact that serial observations made at 24,48 , and 72 hours on the same samples gave

\footnotetext{
${ }^{3}$ Sigma Chemical Co., St. Louis, Mo.

${ }^{4}$ Kindly supplied by Dr. Eugene A. Davidson, Durham, N. C.
}

similar chain length values rather than evidence for progressive degradation.

Neutral sugar. The concentration of neutral sugar, as galactose, in the ethanol-precipitated fractions was decreased in the osteoarthritic cartilage samples, although the samples showing minimal osteoarthritis were not significantly different from normal (Table II). The decrease in keratan sulfate plus glycoprotein concentration, therefore, was not so great as the fall in chondroitin sulfate concentration. As a result, the ratio of chondroitin sulfate to neutral sugar was considerably lower in the abnormal samples; as the severity of osteoarthritis increased, the ratio of chondroitin sulfate to neutral sugar fell, indicating proportionately greater loss of chondroitin sulfate than of the components containing neutral sugar.

In vitro uptake of ${ }^{35} \mathrm{SO}_{4}$ and acetate $-{ }^{14} \mathrm{C}$. Cartilage samples obtained at autopsy were incubated with labeled precursors to study the nature of the compounds synthesized. Previous reports of increased ${ }^{35} \mathrm{~S}$ uptake in osteoarthritic cartilage samples compared with normal areas from the same individuals were based on radioautography or counting digests of whole cartilage fragments washed after incubation (1). More convincing evidence that the label was actually incorporated into chondroitin sulfate was sought by separating the fractions obtained by ethanol precipitation. The incorporation of isotope into the chondroitin sulfate precipitated at $40 \%$ ethanol was compared in normal and abnormal sites from the same knee joint. Presumably because of variations in time between death and autopsy, there were wide variations in total radioactivity incorporated into the chondroitin sulfate between individuals; however, comparison of normal to abnormal sites in each knee was possible. The specific activity of the chondroitin sulfate in the $40 \%$ ethanol precipitate was considerably higher in the osteoarthritic samples compared with normal cartilage. On the basis of the weight of the cartilage samples incubated, there was no consistent relationship between the normal and abnormal sites. Only 20\% of the abnormal samples showed higher incorporation of radiosulfate than the corresponding normal sites; there was no relationship between severity of the osteoarthritis, concentration of chondroitin sulfate, or age of the individual and the ${ }^{35} \mathrm{~S}$ findings (Table III). 
TABLE III

${ }^{35} \mathrm{SO}_{4}$ and acetate ${ }^{-14} \mathrm{C}$ incorporation by normal and osteoarthritic cartilage samples into polysaccharide precipitated by $40 \%$ ethanol

\begin{tabular}{|c|c|c|c|c|c|}
\hline \multirow[t]{2}{*}{$\begin{array}{l}\text { A. Representative individual cases } \\
\text { Isotopic } \\
\text { compound }\end{array}$} & \multirow[t]{2}{*}{ Patient } & \multirow{2}{*}{ Cartilage sample } & \multirow{2}{*}{$\begin{array}{c}\begin{array}{c}\text { Chondroitin } \\
\text { sulfate con- } \\
\text { centration }\end{array} \\
\%\end{array}$} & \multicolumn{2}{|c|}{$\begin{array}{l}\text { Radioactivity in } \\
40 \% \text { fraction }\end{array}$} \\
\hline & & & & $\begin{array}{l}c p m / 100 \\
m g\left(10^{3}\right)\end{array}$ & $\underset{\left(1 O^{2}\right)}{c p m / \mu m o l e}$ \\
\hline \multirow[t]{2}{*}{${ }^{35} \mathrm{SO}_{4}$} & $\begin{array}{l}\text { 61-year-old } \\
\text { male }\end{array}$ & $\begin{array}{l}\text { Normal } \\
\text { Osteoarthritic } \\
\text { Osteoarthritic }\end{array}$ & $\begin{array}{l}1.12 \\
0.427 \\
0.475\end{array}$ & $\begin{array}{l}7.3 \\
3.6 \\
5.7\end{array}$ & $\begin{array}{l}12.9 \\
17.6 \\
25.1\end{array}$ \\
\hline & $\begin{array}{l}\text { 62-year-old } \\
\text { male }\end{array}$ & $\begin{array}{l}\text { Normal } \\
\text { Osteoarthritic } \\
\text { Osteoarthritic } \\
\text { Osteoarthritic }\end{array}$ & $\begin{array}{l}1.04 \\
0.155 \\
0.157 \\
0.745\end{array}$ & $\begin{array}{r}45.6 \\
15.6 \\
156.0 \\
71.3\end{array}$ & $\begin{array}{r}98.9 \\
215.0 \\
163.0 \\
177.0\end{array}$ \\
\hline Acetate $-{ }^{14} \mathrm{C}$ & $\begin{array}{l}80 \text {-year-old } \\
\text { female }\end{array}$ & $\begin{array}{l}\text { Normal } \\
\text { Normal } \\
\text { Osteoarthritic } \\
\text { Osteoarthritic }\end{array}$ & $\begin{array}{l}1.43 \\
1.52 \\
0.921 \\
0.334\end{array}$ & $\begin{array}{l}4.5 \\
5.1 \\
2.3 \\
2.3\end{array}$ & $\begin{array}{r}4.3 \\
4.9 \\
11.2 \\
3.6\end{array}$ \\
\hline $\begin{array}{c}\text { B. Means of specific activity } \\
\text { Isotopic } \\
\text { compound }\end{array}$ & \multicolumn{2}{|c|}{ Cartilage sample } & $\begin{array}{c}\text { No. of } \\
\text { observations }\end{array}$ & \multicolumn{2}{|l|}{ Mean $\left(\times 10^{2}\right)$} \\
\hline${ }^{35} \mathrm{SO}_{4}$ & \multicolumn{2}{|c|}{$\begin{array}{l}\text { Normal } \\
\text { Minimal osteoarthritis } \\
\text { Advanced osteoarthritis }\end{array}$} & $\begin{array}{l}17 \\
10 \\
18\end{array}$ & \multicolumn{2}{|l|}{$\begin{array}{r}35.6 \\
81.6 \\
133.1\end{array}$} \\
\hline Acetate $-{ }^{14} \mathrm{C}$ & $\begin{array}{l}\text { Normal } \\
\text { Osteoar }\end{array}$ & . & $\begin{array}{l}5 \\
7\end{array}$ & \multicolumn{2}{|l|}{$\begin{array}{l}11.0 \\
20.0\end{array}$} \\
\hline
\end{tabular}

Water and ash content (Table IV). The water content of normal articular cartilage averaged $67.9 \%$, whereas in osteoarthritic cartilage samples it averaged $74.8 \%$ of the wet weight. The ash weights determined on the same cartilage samples showed no significant difference between normal and abnormal sites.

Influence of age. The normal cartilage samples from different individials were compared on the basis of age; almost all the samples were from individuals between the ages of 30 and 80 years. In that age range, no trend was noted with increasing age for the concentration of chondroitin sulfate or of compounds containing neutral sugar, the ratio of chondroitin sulfate to these com-

TABLE IV

Water content and ash weights of normal and osteoarthritic articular cartilage

\begin{tabular}{|c|c|c|c|c|}
\hline & $\begin{array}{l}\text { No. of } \\
\text { obser- } \\
\text { vations }\end{array}$ & $\begin{array}{l}\text { Water } \\
\text { content }\end{array}$ & Ash content & $\begin{array}{l}\text { Concentra- } \\
\text { tion of } \\
\text { chondroitin } \\
\text { sulfate }\end{array}$ \\
\hline & & $\%$ wet wt & $\% d r y w t$ & $\mathrm{~g} / 100 \mathrm{ml}$ \\
\hline Normal & 26 & $67.9 \pm 0.84$ & $4.20 \pm 0.21$ & $1.20 \pm 0.046$ \\
\hline Osteoarthritic & 24 & $74.8 \pm 1.33$ & $4.34 \pm 0.70$ & $0.522 \pm 0.167$ \\
\hline $\mathrm{p}$ & & $<0.01$ & $<0.7$ & $<0.001$ \\
\hline
\end{tabular}

pounds, the chain length of the chondroitin sulfate, the water content, or the ash content of these normal cartilage samples (Figures 1 and 2).

\section{Discussion}

The decrease in average chain length of the chondroitin sulfate in osteoarthritic cartilage lesions and the decreased ratio of chondroitin sulfate to compounds containing neutral sugar (glycoprotein plus keratan sulfate) suggest a role of a depolymerase such as hyaluronidase in chondroitin sulfate degradation in these lesions. Alternatively, the decreased chain length might result from preferential synthesis of lower molecular weight chondroitin sulfate; an attempt to demonstrate this by separation of relatively low and relatively high molecular weight fractions on the basis of ethanol solubility showed a similar pattern of radiosulfate incorporation in normal and osteoarthritic cartilage samples. These results, however, cannot be considered conclusive, and the alternative explanation, preferential synthesis of lower molecular weight chondroitin sulfate, remains a possibility. In addition, it should be clearly pointed out that these findings in no way 

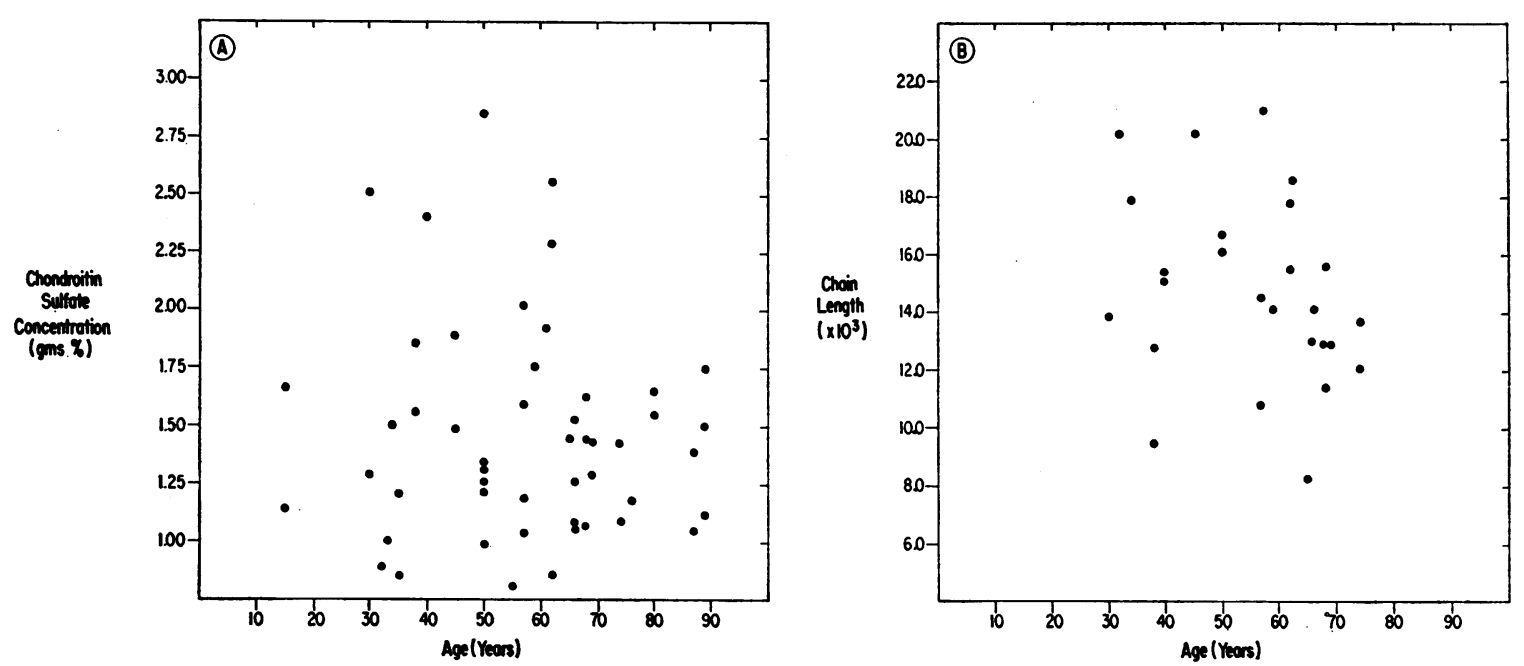

Fig. 1. The chondroitin sulfate concentration (A) and Chain length (B) in Normal articular Cartilage FROM THE KNEE JOINT IN INDIVIDUALS OF VARIOUS AGES.

eliminate the possibility of a role of proteolytic enzyme or a combination of the two types of polysaccharide removal. A combined effect seems likely, since the decreased neutral sugar level found in the extracts of osteoarthritic cartilage indicates that the metabolic abnormality is not limited to chondroitin sulfate. However, the decrease in the concentration of compounds containing neutral sugar is negligible in early lesions. Keratan sulfate and glycoprotein are not degraded by hyaluronidase; turnover of keratan sulfate in intervertebral disc tissue is exceedingly slow (14) and the mechanism of breakdown is not known.
In view of the possibility of a role of hyaluronidase in the loss of chondroitin sulfate from osteoarthritic cartilage, the source of this enzyme comes under scrutiny. Although an enzyme with characteristics of testicular hyaluronidase is widely distributed in animal tissues and present in human serum, synovial tissue, and synovial fluid (4), it has not been found in articular or epiphyseal cartilage in spite of numerous attempts by a variety of methods in our laboratory. Hyaluronidase, an acid $\mathrm{pH}$ optimal hydrolytic enzyme, is associated with lysosomes in liver (15); several lysosomal enzymes are easily demonstrable in cartilage sam-
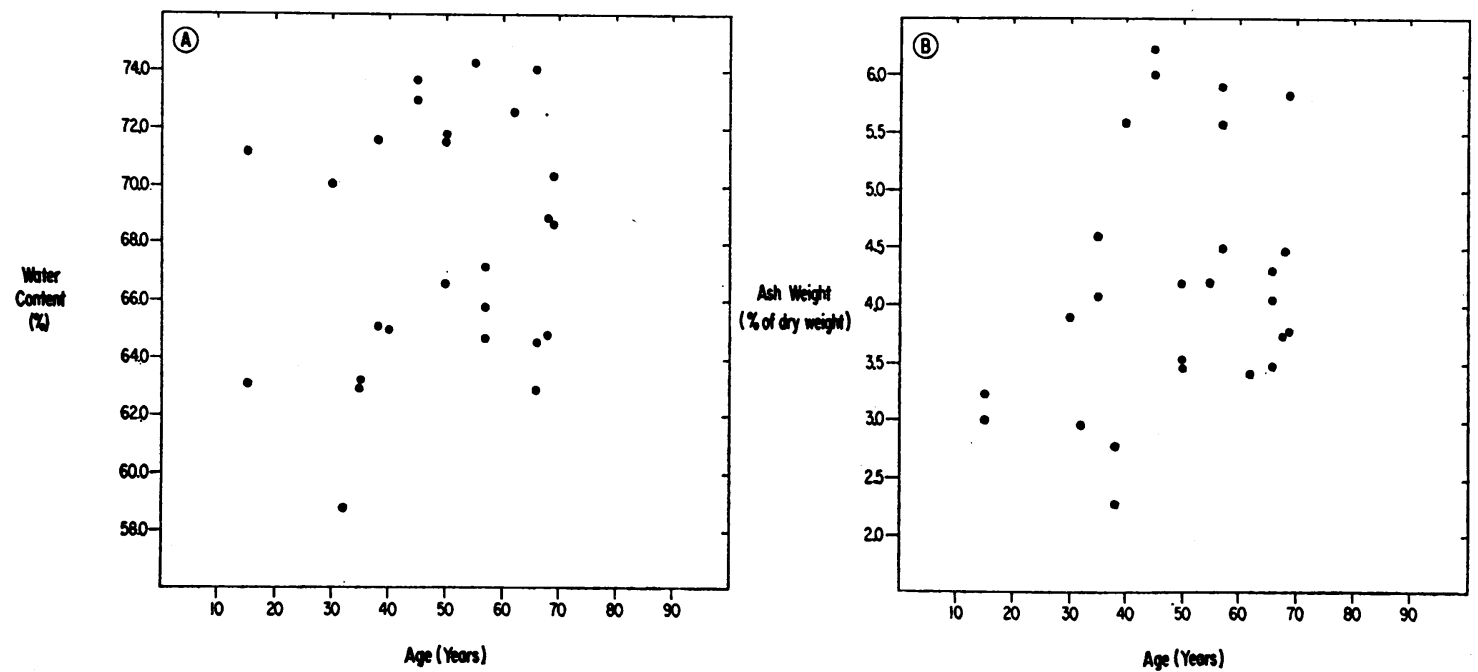

Fig. 2. The water content (A) ANd ASH weight (B) of NORMal articular cartilage From the KNEe joint IN INDIVIDUALS OF VARIOUS AGES. 
ples, but hyaluronidase has not been identified. Further investigation of possible sources of the enzyme and of factors influencing its activity are needed, as are studies of factors influencing the rate of synthesis of chondroitin sulfate by normal and abnormal articular cartilage.

Although Collins and McElligott (1) reported increased radiosulfate uptake by osteoarthritic cartilage lesions, our data failed to show consistently increased incorporation into fractions containing chondroitin sulfate, on the basis of the weight of cartilage samples incubated. Increase in the specific activity of the radiosulfate or acetate $-{ }^{14} \mathrm{C}$ was virtually consistent, pointing to increased turnover of the chondroitin sulfate in the osteoarthritic lesions. These findings could have resulted from increased diffusion of isotope into abnormal samples, but this seems unlikely since the cartilage was carefully diced into the smallest size fragments obtainable to provide maximal surface area and to minimize this variable. The greater cellularity of osteoarthritic lesions $(1,2)$ could have been responsible for the increased ${ }^{35} \mathrm{~S}$ uptake; the data cannot be interpreted as showing increased synthesis per cell but, nevertheless, they do seem to indicate increased turnover in the lesions.

The finding of increased water content of osteoarthritic cartilage was unexpected in view of the decreased chondroitin sulfate concentration. A proportionality between polysaccharide concentration and water content is usually found in connective tissues, and the divergence in this instance is interesting particularly since the lower chain length of the chondroitin sulfate and the decreased ratio of chondroitin sulfate to protein (2) indicate that the residual protein polysaccharide in the osteoarthritic lesions is qualitatively altered.

The failure to find a change in concentration or qualitative nature of the polysaccharide with increasing age in articular cartilage is consonant with our earlier observations (2), and in contrast to the findings of Kaplan and Meyer on costal cartilage (16). The age ranges studied are limited to older adults; no statements can be made comparing children or young adults, but the age range observed includes the period of most frequent development and progression of osteoarthritis. Other studies of articular cartilage have re- vealed an absence of age dependent changes in the concentration of hexosamine (17), total solids, percentage of extracellular and intracellular solids, total sulfate, and total potassium (18), although an increase in intracellular water with a decrease in extracellular water was found in older age groups (18). The failure to find significant biochemical changes in aged but normal articular cartilage and the focal distribution of the biochemical as well as pathological changes in this disease point to the need for studies of focal factors influencing metabolic phenomena in articular cartilage in analyzing the pathogenesis of osteoarthritis.

\section{Summary}

Osteoarthritic cartilage lesions show a decrease in chondroitin sulfate concentration and chain length and a decreased ratio of chondroitin sulfate to compounds containing neutral sugar, keratan sulfate plus glycoprotein. This is evidence for a role of a depolymerase such as hyaluronidase in the metabolic breakdown of chondroitin sulfate in these lesions.

In vitro incubation with ${ }^{35} \mathrm{SO}_{4}$ and acetate- ${ }^{14} \mathrm{C}$ results in an increased specific activity of the chondroitin sulfate in osteoarthritic cartilage lesions, indicating increased turnover of the polysaccharide compared to normal cartilage sites.

The water content of osteoarthritic cartilage is increased despite the decreased chondroitin sulfate concentration. The ash content of these lesions is not significantly altered.

Comparison of normal specimens from individuals ranging in age from 30 to 80 years revealed no influence of age on the concentration or chain length of chondroitin sulfate, the concentration of compounds containing neutral sugar, the water content, or the ash content of articular cartilage.

\section{References}

1. Collins, D. H., and T. F. McElligott. Sulphate $\left({ }^{35} \mathrm{SO}_{4}\right)$ uptake by chondrocytes in relation to histological changes in osteoarthritic human articular cartilage. Ann. rheum. Dis. 1960, 19, 318.

2. Bollet, A. J., J. R. Handy, and B. C. Sturgill. Chondroitin sulfate concentration and protein-polysaccharide composition of articular cartilage in osteoarthritis. J. clin. Invest. 1963, 42, 853.

3. Greenawald, K. A., and T. T. Tsaltas. Papain induced chemical changes in adult rabbit cartilage 
matrix. Proc. Soc. exp. Biol. (N. Y.) 1964, 117, 885.

4. Bollet, A. J., W. M. Bonner, Jr., and J. L. Nance. The presence of hyaluronidase in various mammalian tissues. J. biol. Chem. 1963, 238, 3522.

5. Chrisman, O. D., and J. M. Fessel. Enzymatic degradation of chondromucoprotein by cell-free extracts of human cartilage. Surg. Forum 1962, 13, 444.

6. Tourtellotte, C. D., R. D. Campo, and D. D. Dziewiatkowski. Degradation of chondromucoprotein by an enzyme extracted from cartilage. Fed. Proc. 1963, 22, 413.

7. Ali, S. Y. The degradation of cartilage matrix by an intracellular protease. Biochem. J. 1964, 93, 611.

8. Partridge, S. M., and D. F. Elsden. The chemistry of connective tissue. 7. Dissociation of the chondroitin sulfate-protein complex of cartilage with alkali. Biochem. J. 1961, 79, 26.

9. Dische, Z. A new specific color reaction of hexuronic acids. J. biol. Chem. 1947, 167, 189.

10. Neuhaus, O. W., and M. Letzring. Determination of hexosamines in conjunction with electrophoresis on starch. Analyt. Chem. 1957, 29, 1230.

11. Partridge, S. M., H. F. Davis, and G. S. Adair. The chemistry of connective tissues. 6 . The constitu- tion of the chondroitin sulfate-protein complex in cartilage. Biochem. J. 1961, 79, 15.

12. Somogyi, M. A reagent for the copper-iodometric determination of very small amounts of sugar. J. biol. Chem. 1937, 117, 771.

13. Seifter, S., S. Dayton, B. Novic, and E. Muntwyler. The estimation of glycogen with the anthrone reagent. Arch. Biochem. 1950, 25, 191.

14. Davidson, E. A., and W. Small. Metabolism in vivo of connective-tissue mucopolysaccharides. I. Chondroitin sulfate $C$ and keratosulfate of nucleus pulposus. Biochim. biophys. Acta (Amst.) 1963, 69, 445.

15. Aronson, N. N., Jr., and E. A. Davidson. Lysosomal hyaluronidase. J. biol. Chem. 1965, 240, 3222.

16. Kaplan, D., and K. Meyer. Ageing of human cartilage. Nature (Lond.) 1959, 183, 1267.

17. Anderson, C. E., J. Ludoweig, H. A. Harper, and E. P. Engleman. The composition of the organic component of human articular cartilage. Relationship to age and degenerative joint disease. J. Bone Jt Surg. 1964, 46-A, 1176.

18. Miles, J. S., and L. Eichelberger. Biochemical studies of human cartilage during the aging process. J. Amer. Geriat. Soc. 1964, 12, 1. 